\title{
PERBANDINGAN SUHU LINGKUNGAN DAN PENGARUH PAKAN TERHADAP PRODUKTIVITAS SAPI PERAH DI DAERAH DENGAN KETINGGIAN BERBEDA
}

\section{Comparison Of Environmental Temperature and Feed Effect on Productivity of Dairy Cattle in the Area With Different Height}

\section{Dela Heraini ${ }^{1}$, Bagus Priyo Purwanto ${ }^{2}$, Suryahadi ${ }^{3}$}

${ }^{1}$ Department of Animal Husbandry, Faculty of Agriculture, Universitas Tanjungpura

Jl. Prof. Dr. H. Hadari Nawawi 78124

${ }^{2}$ Department of Production and Animal Husbandry Technology Science, Faculty of Animal Science, Bogor Agricultural University

${ }^{3}$ Department of Nutrition and Feed Technology Science, Faculty of Animal Science, Bogor Agricultural University

J1. Raya Dramaga, Kampus IPB Dramaga Bogor, West Java, 16680

E-mail: dhe2612@gmail.com

\begin{abstract}
This study was done to compare the environmental temperature and the effect of feed management on dairy cattle productivity in KUTT Suka Makmur Grati Pasuruan. Primary data were collected by questionare based interview to the farmers at different height areas those were 40 farmers in lowland area and 40 farmers in highland area. Data were analyzed using descriptive statistics and quant itative methods. The results showed that temperatures in the lowlands were higher at around $240 \mathrm{C}-27 o \mathrm{C}$, so cattle experiencing heat stress and the impact was cattle consumed less feed, while the availability of water was limited. In contrast, the highlands temperature was relatively low, about $220 \mathrm{C}-24 o \mathrm{C}$. The cattle in highland was fed with elephant grass with a good nutrient content, so the cattle was able to produced well.
\end{abstract}

Keywords: Dairy Cattle, Environment, Feed Effect, Productivity, Temperature

\section{PENDAHULUAN}

Sektor peternakan sapi perah di Jawa Timur pada umumnya masih berskala peternakan rakyat dengan jumlah sapi kurang dari 20 ekor per unit usaha peternakan. Pada tahun 2013, populasi sapi perah di Jawa Timur sebanyak 237.673 ekor dan produksi susu yang dihasilkan mencapai 416.418.654 liter (Dinas Peternakan Provinsi Jawa Timur, 2014).

Ternak sapi perah yang dikembangkan di wilayah penelitian merupakan jenis sapi perah Friesian Holstein (FH). Sapi FH di Indonesia berasal dari negara beriklim sedang yang memerlukan suhu yang optimum (sekitar 18oC) dengan kelembaban 55\% untuk mencapai produksi maksimalnya. Menurut Yani et al. (2006) sapi FH menunjukkan penampilan produksi terbaik jika ditempatkan pada suhu lingkungan yang nyaman yaitu berkisar $13-18^{\circ} \mathrm{C}$ dan apabila melebihi suhu nyaman tersebut maka ternak akan melakukan penyesuaian secara fisiologis dan secara tingkah laku (behavior), sehingga usaha peternakan sapi perah Indonesia pada umumnya dipelihara pada daerah yang memiliki ketinggian lebih dari 800 mdpl dengan tujuan untuk penyesuaian lingkungan. Lebih lanjut Yani et al. (2006) menyatakan sapi yang tidak ditempatkan pada kondisi suhu yang nyaman akan mengalami cekaman panas dan hal ini akan berpengaruh pada penurunan nafsu makan dan meningkatkan konsumsi minum, peningkatan temperature tubuh, dan perubahan tingkah laku.

Pakan bagi ternak sapi perah digunakan untuk memenuhi kebutuhan hidup pokok, kebuntingan, dan produksi susu induk, serta kebutuhan untuk pertumbuhan bagi ternak muda. Upaya yang dilakukan agar sapi perah dapat berproduksi secara optimal adalah perlunya ketersediaan pakan yang cukup baik, baik kualitas maupun kuantitasnya, artinya pakan yang tersedia mampu memenuhi kebutuhan nutrisi sesuai 
dengan kebutuhan ternak, tidak kekurangan atau berlebihan.

Pemahaman terhadap kondisi suhu lingkungan yang sesuai dan manajemen pemberian pakan yang baik akan berpengaruh terhadap produksi susu sapi perah, dimana manajemen yang baik diharapkan mampu menghasilkan output produksi yang optimal. Penelitian ini bertujuan untuk mengkaji perbandingan suhu lingkungan dan pengaruh pakan yang diberikan terhadap produktivitas ternak sapi perah pada daerah dengan ketinggian yang berbeda.

\section{MATERI DAN METODE}

Penelitian ini dilaksanakan pada bulan Januari 2015 di kawasan peternakan sapi perah yang tergabung dalam anggota KUTT Suka Makmur, Kecamatan Grati, Kabupaten Pasuruan, Provinsi Jawa Timur. Pengambilan data dilakukan pada periode awal musim penghujan. Pemilihan Kecamatan Grati sebagai tempat penelitian karena kawasan tersebut merupakan kawasan peternakan rakyat sapi perah terbesar di Jawa Timur dan memiliki beberapa ketinggian yang berbeda dalam satu wilayah yaitu dataran rendah 0 - 600 mdpl dan dataran tinggi $600-1500$ mdpl.

\section{Materi}

Penelitian dilakukan dengan peternak responden yang tergabung dalam anggota KUTT Suka Makmur. Peternak tersebar pada beberapa kelompok ternak dengan wilayah yang berbeda. Pemilihan peternak responden dalam survei dilakukan dengan metode Area sampling atau sampel wilayah secara acak. Metode ini memberikan kesempatan yang sama untuk pengambilan sampel pada setiap elemen populasi. Peternak responden yang terpilih terdiri dari peternak yang memiliki sapi perah kurang dari
25 ekor terdiri dari 40 peternak di wilayah dataran rendah dan 40 peternak berada di wilayah dataran tinggi. Hal ini merujuk pada Cooper dan Emory (1996), dimana untuk ukuran sampel yang cukup besar $(n \geq 30)$ diasumsikan populasi menyebar normal. Peralatan yang digunakan adalah alat tulis, pita ukur untuk mengukur lingkar dada sapi, termometer bola kering, bola basah, lembar kuesioner (lembar panduan wawancara), dan peralatan lain yang diperlukan.

\section{Metode \\ Koleksi dan Analisis Data}

Penelitian ini di desain dengan metode survei yang bersifat deskriptif kualitatif dan kuantitatif. Penelitian dilakukan menggunakan data pertanyaan (kuesioner) sebagai alat pengumpulan data yang pokok. Data primer diperoleh melalui wawancara responden dan observasi langsung terhadap kegiatan peternak. Data sekunder yang digunakan yaitu data peternak yang tergabung dalam KUTT Suka Makmur serta data-data lain yang diperoleh dari kantor Kecamatan Grati dan Dinas Peternakan Kabupaten Pasuruan maupun data dari koperasi. Data yang dikumpulkan berupa jenis dan jumlah pakan yang diberikan, pengukuran suhu, pengukuran lingkar dada dan bobot badab sapi. serta data-data pendukung lainnya.

\section{Pengukuran suhu dan kelembaban udara}

Suhu dan kelembaban udara diukur pada pagi hari pukul $06.00 \mathrm{WIB}$, siang hari pukul 12.00 WIB, dan malam hari pukul 19.00 WIB. Rata-rata suhu dan kelembaban udara wilayah dataran rendah berbeda dengan suhu udara yang ada di dataran tinggi. Suhu dan kelembaban udara wilayah dataran rendah dan dataran tinggi diukur dengan menggunakan termometer bola kering dan bola basah. Hasil yang diperoleh disajikan pada Tabel 1.

Tabel 1. Suhu dan kelembaban udara dataran rendah dan dataran tinggi

\begin{tabular}{lccc} 
& $\begin{array}{c}\text { Pagi } \\
(\mathbf{0 6 . 0 0} \text { WIB })\end{array}$ & $\begin{array}{c}\text { Siang } \\
(\mathbf{1 2 . 0 0} \text { WIB })\end{array}$ & $\begin{array}{c}\text { Malam } \\
(\mathbf{1 9 . 0 0} \text { WIB })\end{array}$ \\
\hline \hline Temperatur $\left({ }^{\mathbf{0}} \mathbf{C}\right):$ & & & \\
\hline Dataran rendah & $24-26$ & $25-27$ & $25-27$ \\
Dataran tinggi & $21-22$ & $23-24$ & $22-23$ \\
\hline Kelembaban (\%): & & & \\
\hline Dataran rendah & $84-96$ & $72-92$ & $78-92$ \\
Dataran tinggi & $84-96$ & $88-93$ & $89-92$ \\
\hline
\end{tabular}




\section{Pengukuran lingkar dada dan bobot badan sapi}

Pendugaan bobot badan sapi di uji dengan menggunakan rumus Schoorl, sapi diukur dengan menggunakan pita ukur yang dilingkarkan ke dada sapi melalui belakang siku pada bagian tersempit dapat dilihat pada Tabel 2.

\section{Karakteristik sampel peternak responden}

Karakteristik sampel peternak responden dataran rendah dan dataran tinggi disajikan pada Tabel 3. Peubah yang diukur meliputi jumlah ternak, konsentrat, jerami padi (wilayah dataran rendah), rumput gajah (wilayah dataran tinggi), serta analisis deskriptif yang meliputi umur peternak, pengalaman beternak, dan pendidikan peternak. Rata-rata peternak memiliki ternak sebanyak 8 ekor di wilayah dataran rendah dan 4 ekor di wilayah dataran tinggi, dengan produksi susu sebesar 6,11 L di wilayah dataran rendah an $11,11 \mathrm{~L}$ di wilayah dataran tinggi lebih lanjut bisa dilihat dalam Tabel 3.

\section{HASIL DAN PEMBAHASAN}

Suhu lingkungan sapi perah yang dipelihara di dua wilayah berbeda menunjukkan wilayah dataran tinggi memiliki kondisi iklim yang rendah dibandingkan dengan suhu udara di wilayah dataran rendah yaitu berkisar antara 21$24^{\circ} \mathrm{C}$ hal ini dapat dilihat pada Tabel 1 . Kondisi suhu rendah memungkinkan ternak berproduksi lebih baik dibandingkan dengan kondisi suhu tinggi. Ternak yang berada dalam kondisi nyaman maka mudah bagi ternak tersebut dalam mencerna pakan yang dikonsumsi karena pakan yang dicerna tidak terbuang menjadi energi untuk bertahan hidup.

Suhu udara yang tinggi sangat tidak menguntungkan bagi ternak, karena akan berpengaruh pada konsumsi pakan ternak, air minum dan tingkah laku. Ternak sapi yang berada di lingkungan yang bersuhu tinggi akan mengalami stres berat dan gagal dalam mengatur panas tubuh. Akibatnya, ternak akan banyak minum air tetapi nafsu makan berkurang dan pakan yang dikonsumsi rendah. Pada penelitian ini sapi perah yang berada di dataran rendah mengkonsumsi hijauan hanya sebesar 26,0951 kg per ekor ternak per hari. Berbeda dengan sistem pemberian hijauan yang ada di wilayah dataran tinggi. Mayoritas sapi perah yang berada di wilayah dataran tinggi mengkonsumsi hijauan lebih banyak yaitu berkisar 46,0578 kg per ekor per hari.

Kemampuan ternak dalam mencerna pakan dan merasa nyaman dengan suhu lingkungan akan berdampak pada bobot tubuh yang besar, hal ini dapat dilihat pada Tabel 2 . Bobot badan sapi di wilayah dataran tinggi berkisar antara 338,56 - 497,29 kg, berbeda dengan sapi yang dipelihara di wilayah dataran rendah yang berbobot badan 201,64 - 449,44. Selain itu, lingkar dada sapi di wilayah dataran rendah lebih kecil di bandingkan dengan lingkar dada sapi di wilayah dataran tinggi yaitu $120-190 \mathrm{~cm}$.

Tabel 2. Perbandingan ukuran lingkar dada dan bobot badan sapi

\begin{tabular}{lccc}
\hline \multicolumn{1}{c}{ Variabel } & Jumlah & \multicolumn{2}{c}{ Rataan } \\
\cline { 3 - 4 } & & Dataran rendah & Dataran tinggi \\
\hline Lingkar dada $(\mathrm{cm})$ & 40 ekor & $120-190$ & $162-201$ \\
Bobot badan $(\mathrm{kg})$ & 40 ekor & $201,64-449,44$ & $338,56-497,29$ \\
\hline
\end{tabular}

Tabel 3. Karakteristik peternak manajemen pakan dan produktivitas sapi perah di dataran rendah dan dataran tinggi

\begin{tabular}{lcc}
\hline \multicolumn{1}{c}{ Variabel } & \multicolumn{2}{c}{ Rataan } \\
\cline { 2 - 3 } & Dataran rendah & Dataran tinggi \\
\hline Jumlah ternak (ST) & 8,8 & 4,875 \\
Produksi susu (liter/ekor/hari) & 6,1138 & 11,115 \\
Pakan konsentrat (kg)/ peternak & 211.500 & 180.000 \\
Jerami padi (kg)/peternak & 26,0951 & - \\
Rumput gajah (kg)/peternak & - & 46,0578 \\
Air minum & Tidak ad-libitum & Ad-libitum \\
Umur peternak (tahun) & Bercampur dengan konsentrat & \\
Pengalaman beternak (tahun) & 42,9 & 39,5 \\
Pendidikan peternak (tahun) & 20,475 & 17,475 \\
\hline
\end{tabular}


Tabel 3 menunjukkan bahwa di wilayah dataran rendah rata-rata peternak berumur 42 tahun dengan rata-rata tingkat pendidikan 6 tahun atau setara dengan tamatan sekolah dasar (SD), dan pengalaman beternak hampir lebih dari 20 tahun. Sedangkan pada wilayah dataran tinggi rata-rata peternak berumur 39 tahun dengan ratarata 6 tahun tingkat pendidikan atau setara dengan sekolah dasar (SD) dan pengalaman beternak sekitar 17 tahun. Rata-rata pendidikan peternak di wilayah dataran rendah dan wilayah dataran tinggi adalah 6 tahun. Pengalaman beternak wilayah dataran rendah berkisar 20 tahun dan 17 tahun di dataran tinggi. Umur peternak wilayah dataran rendah sekitar 42 tahun sedangkan wilayah dataran tinggi rata-rata peternak berumur 39 tahun.

Pola pemeliharan ternak dengan metode tradisional biasanya adalah peternak-peternak yang sudah beternak secara turun temurun yang diwariskan oleh orangtua terdahulu, sehingga informasi dan teknologi terbarukan sulit untuk bisa diterapkan. Berbeda dengan peternak yang memiliki tingkat pendidikan yang tinggi dan umur peternak yang masih muda biasanya akan mudah dalam menerima dan merapkan teknologiteknologi terbarukan dalam bidang peternakan.

Tabel 3 juga menunjukkan sapi perah di wilayah dataran rendah mampu memproduksi susu 6 liter per ekor per hari, kondisi ini bisa dijelaskan bahwa ternak yang berada di wilayah dataran rendah cenderung memiliki penampilan tubuh yang lebih kecil, seperti yang terlihat pada Tabel 2. Pada umumnya produksi susu yang tinggi dipengaruhi oleh besarnya ukuran tubuh atau bobot badan. Pada penelitian ini terdapat korelasi positif antara volume ambing dan bobot badan terhadap produksi susu. Menurut Cannas (2004) ternak yang memiliki bobot badan tinggi, proporsi penggunaan energi untuk hidup pokok ternak menjadi lebih sedikit dan kelebihan energi pada ternak bisa digunakan untuk produksi susu.

Rata-rata ternak di daerah dataran rendah mengkonsumsi konsentrat dan hijauan jerami padi sebesar $211.500 \mathrm{~kg}$ per ekor per hari dan 26.0951 $\mathrm{kg}$ per ekor per hari per rumah tangga peternak. Kondisi ini berhubungan erat dengan jumlah satuan ternak (ST) yang dipelihara oleh peternak dengan rata-rata ST berjumlah 8 ekor ternak yang berproduksi. Pakan merupakan salah satu bagian yang terpenting bagi hidup pokok ternak termasuk untuk memenuhi kebutuhan produksi. Perimbangan antara bahan kering hijauan dan konsentrat untuk mencapai produksi susu yang tinggi belum dapat diaplikasikan oleh peternak yang berskala peternakan rakyat, kondisi ini didukung dengan harga konsentrat yang relatif mahal dibandingkan dengan harga penjualan susu oleh peternak. Rata-rata kondisi seperti ini dialami oleh setiap unit usaha peternakan rakyat termasuk yang ada di wilayah dataran rendah maupun di dataran tinggi. Harga susu yang diterima peternak yaitu Rp. 4.500,00 per liter per hari, tidak sebanding dengan biaya pembelian konsentrat yang dibeli seharga Rp. 255.000,00 untuk konsentrat jenis SPL 01 dan Rp. 395.000,00 untuk konsentrat jenis HIPRO.

Cara pemberian konsentrat di wilayah dataran rendah masih dicampur dengan ampas tahu, onggok dan air minum. Sumber air yang digunakan peternak dataran rendah adalah air sumur, namun air sumur terasa sedikit asin karena wilayah dataran rendah hampir mendekati wilayah pantai dan ada beberapa peternak yang membeli air, sehingga kebutuhan ternak terhadap konsumsi air masih belum terpenuhi, sedangkan sapi $\mathrm{FH}$ yang ditempatkan dilingkungan yang bersuhu tinggi secara fisiologis akan mengalami cekaman panas. Cekaman panas akan berakibat pada meningkatnya konsumsi minum, peningkatan suhu tubuh, respirasi dan denyut jantung serta terjadinya peningkatan panas melalui penguapan. Menurut Santoso et al. (2009) kebutuhan dasar seekor sapi perah terhadap air adalah lebih kurang 40 liter per hari terutama di daerah yang bersuhu tinggi.

Konsumsi hijauan di wilayah dataran rendah cenderung lebih sedikit dibanding wilayah dataran tinggi. Sapi perah wilayah dataran rendah hanya mengkonsumsi hijauan sebanyak 26,0951 $\mathrm{kg}$ per ekor per hari dan sapi yang berada di wilayah dataran tinggi mengkonsumsi hijauan sebanyak 46,0578 kg per ekor per hari. Menurut Kadarsi (2004) ternak yang berada di wilayah dataran rendah yang bersuhu dan kelembaban tinggi akan mengalami penurunan konsumsi pakan, sehingga ternak cenderung tidak suka makan, berbeda dengan ternak yang berada di wilayah dataran tinggi yang bersuhu rendah nafsu makan ternak akan meningkat.

Noviyanti et al. (2013) menyatakan bahwa hijauan menjadi sumber kehidupan penting dalam perkembangan ternak, oleh karena itu hijauan diharapkan yang berkualitas baik dan mudah dicerna oleh ternak dan peningkatan produksi susu dapat dilihat dari semakin banyaknya konsumsi pakan dalam bentuk bahan kering, TDN dan protein yang terkandung dalam bahan pakan kemudian disintesa menjadi zat-zat nutrient dalam darah sehingga terjadi penyerapan dan dapat meningkatnya produksi susu dan kadar protein serta lemak dalam susu. Sehingga peningkatan konsumsi pakan dan pemberian hijauan yang 
berkualitas baik pada sapi akan berpengaruh pada produksi susu yang dihasilkan.

Penampilan sapi perah yang ada di wilayah dataran tinggi cenderung lebih besar dibandingkan dengan penampilan tubuh sapi di wilayah dataran rendah. Seperti yang terlihat pada Tabel 2. Sapi perah yang ada di wilayah dataran tinggi memiliki bobot badan sekitar $338 \mathrm{~kg}$ sampai $497 \mathrm{~kg}$, sedangkan sapi perah yang berada di wilayah dataran rendah memiliki bobot badan sekitar $201 \mathrm{~kg}$ sampai $449 \mathrm{~kg}$. Selain faktor suhu dan kelembaban, pakan yang diberikan juga mempengaruhi kondisi tubuh ternak. Sapi perah yang berada di daerah dataran tinggi diberikan pakan berupa rumput gajah sedangkan ternak di wilayah dataran rendah mengkonsumsi jerami padi. Rumput gajah memiliki nilai kandungan nutrisi yang berbeda dengan jerami padi seperti yang diberikan keternak pada daerah dataran rendah. Kandungan nutrisi rumpat gajah dan jerami padi dapat dilihat pada Tabel 4 .

Menurut Noviyanti et al. (2013) rumput gajah merupakan hijauan yang memiliki protein kasar (PK) sebesar 15.37\%, bahan kering (BK) sebesar $12.88 \%$ dan memiliki energi sekitar $58.31 \%$ TDN, sedangkan jerami padi termasuk kedalam kelompok hijauan yang berkualitas rendah yaitu memiliki PK di bawah $4 \%$ dari BK dan memiliki energi dibawah $40 \%$ TDN dari BK. Pemberian konsentrat pada ternak di wilayah dataran tinggi dan dataran rendah juga berbeda. Ternak yang berada di wilayah dataran tinggi diberikan konsentrat berupa SPL HIPRO sedangkan ternak di wilayah dataran rendah diberika konsentrat jenis SPL 01. Perbedaan kandungan nutrisi dari kedua jenis hijauan dan konsentrat tersebut disajikan pada Tabel 4.

Rata-rata ternak yang ada di wilayah dataran tinggi mengkonsumsi konsentrat dan hijauan rumput gajah sebesar $257.9150 \mathrm{~kg}$ per hari dan $46,0578 \mathrm{~kg}$ per hari per rumah tangga peternak. Kondisi ini berhubungan erat dengan jumlah satuan ternak (ST) yang dipelihara oleh peternak dengan rata-rata ST berjumlah 4 ekor ternak yang berproduksi. Sapi perah membutuhkan zat pakan yang lebih untuk mencukupi kebutuhan produksinya. Namun demikian, sapi perah sebaiknya dikelompokkan dan diberi pakan berdasarkan produksi susu dan status produksinya.

$$
\text { Menurut McCullough }
$$
perbandingan antara bahan kering hijauan dengan konsentrat adalah 60:40, namun jika hijauan yang diberikan merupakan hijauan dengan kualitas rendah maka perbandingan antara BK hijauan dengan konsentrat dapat diubah menjadi 55:45, sedangkan jika hijauan yang diberikan berkualitas sedang sampai tinggi maka perbandingan BK hijauan dengan konsentrat dapat berubah menjadi 64:36. McCullough (1973) juga menyatakan bahwa perbandingan hijauan dan konsentrat yang diberikan sebesar 90:10 maka produksi susu yang tinggi tidak akan dapat dicapai namun kadar lemak susu mengalami peningkatan. Sedangkan apabila BK pakan berupa konsentrat diberikan $100 \%$ maka produksi susu yang tinggi dapat dicapai, namun kadar lemak susu menurun secara drastis. Kadar lemak susu yang tinggi merupakan salah satu persyaratan kualitas susu yang diterima oleh Industri Pengolahan Susu (IPS). Menurut Siregar (1992) bahwa penurunan kadar lemak susu sebagai akibat dari pemberian pakan konsentrat tanpa hijauan itu terjadi karena kurang terbentuknya asam asetat dalam rumen, akibat tidak tersedianya hijauan dalam rumen karena asam asetat sangat diperlukan oleh sapi dalam pembentukan lemak susu.

Tabel 4. Kandungan nutrisi hijauan makanan ternak dan konsentrat (\%)

\begin{tabular}{lccccc}
\hline \multicolumn{1}{c}{ Hijauan* } & $\begin{array}{c}\text { Bahan kering } \\
(\mathbf{B K})\end{array}$ & $\begin{array}{c}\text { Protein } \\
\text { kasar (PK) }\end{array}$ & $\begin{array}{c}\text { Serat Kasar } \\
(\mathbf{S K})\end{array}$ & $\begin{array}{c}\text { Lemak Kasar } \\
(\mathbf{L K})\end{array}$ & $\begin{array}{c}\text { Energi } \\
(\mathbf{T D N})\end{array}$ \\
\hline \hline $\begin{array}{l}\text { Rumput gajah } \\
\text { (dataran tinggi) }\end{array}$ & 21,0 & 9,6 & 32,7 & 1,9 & 52,4 \\
$\begin{array}{l}\text { Jerami padi } \\
\text { (dataran rendah) }\end{array}$ & 86,0 & 3,7 & 35,9 & 1,7 & 39,0 \\
\hline \multicolumn{1}{|c|}{ Konsentrat** } & $\begin{array}{l}\text { Kadar air } \\
\text { maksimal }\end{array}$ & $\begin{array}{c}\text { TDN } \\
\text { minimal }\end{array}$ & $\begin{array}{c}\text { Protein } \\
\text { kasar } \\
\text { minimal }\end{array}$ & $\begin{array}{c}\text { NDF } \\
\text { maksimal }\end{array}$ & $\begin{array}{c}\text { Lemak kasar } \\
\text { maksimal }\end{array}$ \\
\hline $\begin{array}{l}\text { SPL HIPRO } \\
\text { (dataran tinggi) }\end{array}$ & 14 & 75 & 20 & 35 & 7 \\
$\begin{array}{l}\text { SPL 01 (dataran } \\
\text { rendah) }\end{array}$ & 14 & 70 & 16 & 35 & 7 \\
\hline
\end{tabular}

Sumber: *PT Nestle Kejayan Factory (2009)

**PT Yellow Feed Kejayan (2014) 
Rata-rata produksi susu sapi daerah dataran rendah lebih sedikit dibandingkan dengan produksi susu sapi yang ada di dataran tinggi, yaitu 2 sampai 10 liter per hari dan 6 sampai 17 liter per hari. Usaha yang dapat dilakukan untuk meningkatkan produksi susu dengan cara menambahkan pakan atau perbaikan sistem pemberian pakan tanpa penambahan biaya. Sapi perah hendaknya diberikan pakan yang berkualitas tinggi sehingga dapat berproduksi sesuai dengan kemampuannya. Perbedaan jenis pakan yang diberikan pada ternak di wilayah dataran rendah dengan dataran tinggi mampu mempengaruhi produksi susu yang dihasilkan.

Frekuensi pemberian pakan juga berpengaruh terhadap produksi susu sapi. Peternak di wilayah dataran rendah seharusnya dapat mengusakan peningkatan pemberian pakan dari satu kali menjadi dua kali sehari atau menjadi tiga kali sehari dengan mempertimbangkan kecukupan ketersediaan pakan dan pakan tidak terbuang banyak. Hal ini diharapkan agar sapi mampu memproduksi susu lebih banyak. Sapi yang sedang berproduksi dan diberikan pakan lebih sering diharapkan mampu meningkatkan produksi susu dan peningkatan kadar lemak susu. Peningkatan susu tersebut terjadi karena energi dan zat-zat makanan yang diperlukan oleh ternak untuk membantu proses produksi susu karena tersedia dalam jumlah banyak

Frekuensi pemberian pakan dan suhu yang kurang optimum menyebabkan ternak yang berada di wilayah dataran rendah cenderung mengkonsumsi pakan lebih sedikit di banding ternak yang ada di dataran tinggi dan hal ini tidak di imbangi dengan ketersediaan air minum secara ad-libitum. Meski demikian, menurut Ma'rifah (2012) jumlah pemberian ransum per hari adalah sebanyak 3.5\% BK dari bobot badan sapi, dan terbagi menjadi dua kali pemberian. Ransum tersebut dapat dipenuhi dengan pemberian hijauan segar (13\% bobot badan) dan konsentrat (1.5\% bobot badan), sedangkan menurut Sutardi (2003) sapi perah berbobot badan $300 \mathrm{~kg}$ sampai $500 \mathrm{~kg}$ dengan produksi susu $10 \mathrm{~kg}$ dibutuhkan bahan kering sebanyak $2.30 \%$ sampai $2,70 \%$ dari bobot hidup dan menurut Sudono (1999) sapi perah laktasi membutuhkan 17\% BK.

\section{SIMPULAN DAN SARAN}

\section{Simpulan}

Suhu lingkungan dataran di rendah relatif lebih tinggi yaitu sekitar $24^{\circ} \mathrm{C}$ sampai $27^{\circ} \mathrm{C}$ sehingga ternak berpotensi mengalami cekaman panas, yang berakibat berkurangnya konsumsi pakan dan tanpa adanya ketersediaan air minum secara ad-libitum. Berbeda dengan ternak yang dipelihara di dataran tinggi, yaitu suhu relatif rendah sekitar $22^{\circ} \mathrm{C}$ sampai $24^{\circ} \mathrm{C}$ dan pakan yang diberikan berupa rumput gajah dengan kandungan nutrisi yang cukup baik, sehingga dengan kondisi seperti ini sapi merasa nyaman dan mampu berproduksi lebih baik.

\section{Saran}

Perbaikan manajemen pemeliharaan dengan mempertimbangkan aspek kualitas nutrisi pakan, ketersediaan air minum secara ad-libitum serta modifikasi lingkungan diperlukan agar produktivitas sapi perah wilayah dataran rendah menjadi baik.

\section{DAFTAR PUSTAKA}

Abdullah, L. 2014. Prospektif agronomi dan Cannas, A. 2004. Feeding of Lactating Ewes. In: Pulina G, editor. Dairy Sheep Nutritional. CABI Publishing. Oxfordshire. South East England.

Cooper, David, R., Emory, C. William. 1996. Metode Penelitian Bisnis. Jilid 1. Edisi ke 5. Erlangga. Jakarta.

Dinas Peternakan Provinsi Jawa Timur. 2014. Potensi Susu Sapi Perah di Jawa Timur. Dinas Peternakan Provinsi Jawa Timur. http//www.disnak.jatimprov.go.id/.

Ma'rifah, S. 2012. Keragaman Koefisien Teknis Produksi Susu Sapi Perah Rakyat Sebagai Landasan Peningkatan Produktifitas Ternak (Kasus Peternakan Sapi Perah Rakyat Pacet Mojokerto). Tesis. Institut Pertanian Bogor. Bogor.

McCullough, M. E. 1973 . Optimum Feeding of Dairy Animals for Meat and Milk. The University of Georgia Press. Athens, USA.

Novianti, J., Purwanto, B.P., Atabani, A. 2013. Respon Fisiologis dan Produksi Susu Sapi Perah FH pada Pemberian Rumput Gajah (Pennisitum Purpureum) dengan Ukuran Pemotongan yang Berbeda. J. Ilmu Prod. Tek. Hasil Peternakan. Vol. 01 No. 3. Hal: 138-146.

PT. Nestle tbk. 2009. Training Module for Dairy Cooperative Personnel. Kejayan Factory. Pasuruan, Jawa Timur.

Santoso, K.A., Dwiyanto, K., Tohamat, T. 2009. Profil Usaha Peternakan Sapi Perah di Indonesia. Pusat Penelitian dan Pengembangan Peternakan. Badan Penelitian dan Pengembangan Pertanian. Bogor. 
Siregar, S. B. 1992. Sistem pemberian pakan dalam upaya meningkatkan produksi susu sapi perah. Balai Penelitian Ternak Ciawi. Wartazoa 2: 3-4.

Sudono A. 1999. Ilmu Produksi Ternak Perah. Fakultas Peternakan. Institut Pertanian Bogor. Bogor.

Sutardi T. 2003. Landasan Ilmu Nutrisi Jilid I. Departemen Ilmu Makanan Ternak
Fakultas Peternakan. Institut Pertanian Bogor.

Yani, A. dan B.P. Purwanto. 2006. Pengaruh Iklim Mikro Terhadap Respon Fisiologis Sapi Peranakan Fries Holland dan Modifikasi Lingkungan untuk Meningkatkan Produktivitasnya (Ulasan). Media Peternakan 29: 1. 